\title{
An outline of the European Quaternary localities with freshwater gastropods: Data on geography and updated stratigraphy
}

\author{
Elisavet Georgopoulou, Thomas A. Neubauer, Andreas Kroh, \\ Mathias Harzhauser, and Oleg Mandic
}

\begin{abstract}
Fossil and subfossil freshwater gastropods of the European Quaternary have been studied extensively by numerous authors during the nineteenth and twentieth centuries. Despite the wealth of information, these papers usually focus on regional aspects. Geographic names, however, may have changed due to politics and the stratigraphy is outdated in many cases. Since then, numerous papers improved the taxonomic understanding of certain groups of freshwater gastropods and revised the often confused nomenclatural history. Nevertheless, no efforts were made to collect and summarize the data on a pan-European scale in order to compare them. This study focuses specifically on recording Pleistocene and Holocene localities of Europe and some adjacent Asian countries bearing freshwater gastropods, combined with updated stratigraphic information when available. This resulted in a dataset of 1473 localities, which may serve as a base for future analyses of Eurasian post-Pliocene freshwater systems and their biota.
\end{abstract}

Elisavet Georgopoulou. Geological-Palaeontological Department, Natural History Museum Vienna, Burgring 7, 1010 Vienna, Austria; Institute for Earth Sciences, University of Graz, Heinrichstraße 26, 8010 Graz, Austria. elisavet.georgopoulou@nhm-wien.ac.at

Thomas A. Neubauer. Geological-Palaeontological Department, Natural History Museum Vienna, Burgring 7, 1010 Vienna, Austria. thomas.neubauer@nhm-wien.ac.at

Andreas Kroh. Geological-Palaeontological Department, Natural History Museum Vienna, Burgring 7 , 1010 Vienna, Austria. andreas.kroh@nhm-wien.ac.at

Mathias Harzhauser. Geological-Palaeontological Department, Natural History Museum Vienna, Burgring 7, 1010 Vienna, Austria. mathias.harzhauser@nhm-wien.ac.at

Oleg Mandic. Geological-Palaeontological Department, Natural History Museum Vienna, Burgring 7, 1010 Vienna, Austria. oleg.mandic@nhm-wien.ac.at

Keywords: freshwater gastropods; database; geo-referenced points; Pleistocene; Holocene

Submission: 2 December 2014. Acceptance: 2 September 2015

Georgopoulou, Elisavet, Neubauer, Thomas A., Kroh, Andreas, Harzhauser, Mathias, and Mandic, Oleg. 2015. An outline of the European Quaternary localities with freshwater gastropods: Data on geography and updated stratigraphy. Palaeontologia Electronica 18.3.48A: $1-9$

palaeo-electronica.org/content/2015/1328-quaternary-gastropods

Copyright: Palaeontological Association September 2015 


\section{INTRODUCTION}

Due to their high preservation potential, shellbearing gastropods are among the most common fossil and subfossil ( $<0.01 \mathrm{Ma}$ ) macro-organisms in Pleistocene and Holocene deposits (Sparks, 1961). Their shells provide valuable information on palaeoenvironmental evolution as geochemical archives (e.g., Leng and Marshall, 2004; Neubauer et al., 2014), as potential palaeoclimatic proxies (e.g., Szymanek et al., 2005; Sümegi et al., 2008; Szymanek, 2011, 2013, 2014) or as ecological indicators, since the ecology of many species is well understood (e.g., Welter-Schultes, 2012 and references therein).

In Europe, Quaternary freshwater gastropod assemblages have been intensively studied during the last 150 years (e.g., Geyer, 1912; Ložek, 1964; Esu and Girotti, 1975; Alexandrowicz, 1999; Limondin-Lozouet et al., 2013). On a regional scale several studies tried to integrate areal and distribution data from different localities bearing Quaternary freshwater and/or terrestrial gastropods. Perhaps the most widely cited work is the comprehensive synopsis of Ložek (1964), who provided not only a complete list of the Quaternary localities of former Czechoslovakia, but also gave a detailed list of the species and their ecology. A significant addition to this effort is the study published by Hóračová et al. (2015) who assembled a complete and updated list of Holocene sites bearing molluscs in the Czech and Slovak Republics. Although shorter, but in the same spirit, Skompski (1989) published an outline of 107 sites in south-eastern Poland bearing fossil and subfossil gastropods. The list was composed of the site name, reference, the sediment type and the age of the deposit. Similarly, Alexandrowicz (2013) summarized the 154 localities with Late Glacial and Holocene lacustrine faunas in northern Poland, while the molluscs of the Eemian Interglacial in 35 sections across Poland were studied by Alexandrowicz and Alexandrowicz (2010). In north-western Europe, several non-marine molluscan faunas were reviewed in an attempt to shed light on the stratigraphic position of the Cromerian (Meijer and Preece, 1996). Moreover, the analysis of the distribution of the land snail Discus ruderatus by Dehm (1967) provided additional information on post-glacial localities including freshwater species in southern Germany. A substantial and up-to-date work on the Quaternary freshwater gastropods of Belarus with data on selected Lithuanian, Polish and Russian localities was recently published by Sanko (2007).
Other notable papers with regional focus include the post-Pliocene non-marine Mollusca of Ireland and the East of England (Kennard and Woodward, 1917, 1922) and the Plio-Pleistocene and Holocene molluscs of Austria (Frank, 2006). These major works are a rich source of information on the freshwater assemblages of the European Quaternary.

Nonetheless, at a pan-European scale, studies compiling and analysing geographic occurrences are missing. Despite the continuous effort to record fossil gastropod assemblages, inconsistencies and uncertainties concerning the stratigraphic ages hamper comparisons and analyses. For example, the use of the stratigraphic ages of the Holocene chronozones, differ depending on the study area and publication date (e.g., Ložek, 1964; Wojciechowski, 1999; Bitinas et al., 2002; Mouthon and Magny, 2014). Another point to address is the difficulty to correlate regional stratigraphy with the international geological timescale (e.g., many Greek localities of the Damatria, Kritika, Kos, Phoka-Elia, Sefto, Stefanena, Tafi and Vokasia formations in Willmann, 1981; Böger, 1983). The problems of correlating literature-based data are to some extent purely conceptual due to changes in definitions of chronostratigraphic units. Hence, the inclusion of the formerly Pliocene Gelasian Stage into the Pleistocene in 2009 shifted the beginning of the Pleistocene from 1.806 Ma to $2.588 \mathrm{Ma}$ (Gibbard et al., 2010; Gradstein et al., 2012) and resulted in potential pitfalls if informal terms such as "early Pleistocene" are interpreted from the literature.

The purpose of this paper is to address the aforementioned need for an integrated study with consistent stratigraphy of the European Quaternary. To our knowledge this is a first attempt to gather all published and accessible information on Quaternary freshwater gastropods bearing localities in Europe and adjacent areas. Attached to this work we provide a fully geo-referenced dataset for 1473 literature-based fossil sites across Europe (see Appendix 1). This work is a substantial expansion of the dataset of Neubauer et al. (2015), which aimed for a comprehensive compendium of the Neogene (sensu Gradstein et al., 2012) localities of Europe with fossil freshwater gastropods. Since the age attributions are still ambiguous in some cases and geographic information is patchy for certain areas, this synopsis has to be considered as first step, which is open to improvements and additions. 


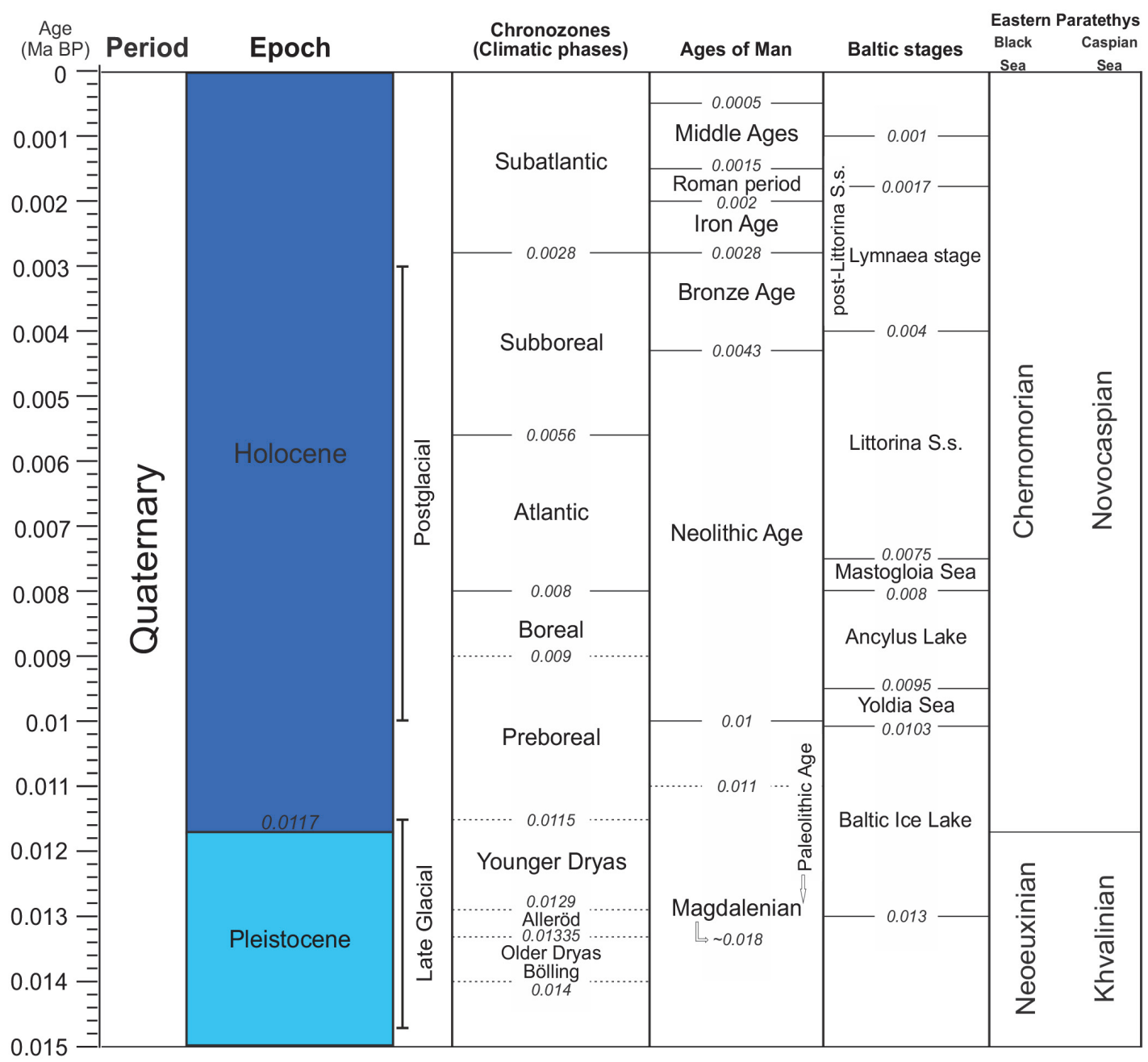

FIGURE 1. Stratigraphic table of the Holocene with suggested boundaries for the climatic phases, the Ages of Man and the Baltic Stages. The Chronozones, the Ages of Man and the Baltic stages of the Latest Pleistocene are also included. The colour code corresponds to the colours in the supplied kml-file. The dates are expressed in Ma BP. For information about the sources see 'Methods'. Abbreviations used in the chart: S.s. = Sea stage.

\section{METHODS}

Data were compiled after an elaborate review of the available literature on the Pleistocene and Holocene fossil and subfossil freshwater gastropod assemblages. The information on the sites and their stratigraphic age derives from original papers but is often updated according to current knowledge. The main sources were online sources (e.g., Biodiversity Heritage Library) as well as numerous journals and books stored at the Geological-Palaeontological and Zoological Departments of the Natural History Museum of Vienna, which were systematically screened for contributions on postPliocene freshwater gastropods. Furthermore, specialists on freshwater gastropods were contacted for copies of their publications when those were not available in any of the sources mentioned above. It is important to note that the list of localities provided in this work is not complete. Despite our efforts, not all literature sources were accessible, whereas others may have been unintentionally overlooked.

The main online source used to georeference the localities was Google ${ }^{\mathrm{TM}}$ Earth 7 software (version 7.1.2.2041). The study area is the European continent including Asia Minor and westernmost Asia (Turkmenistan). These regions were included due to their common palaeogeographic history (Rögl, 1998; Popov et al., 2004). In total, stratigraphic information was extracted from 421 publications (see Appendix 1). The stratigraphic tables (Figures 1,2) are based on the global chronostratigraphic correlation table for the last 2.7 million 


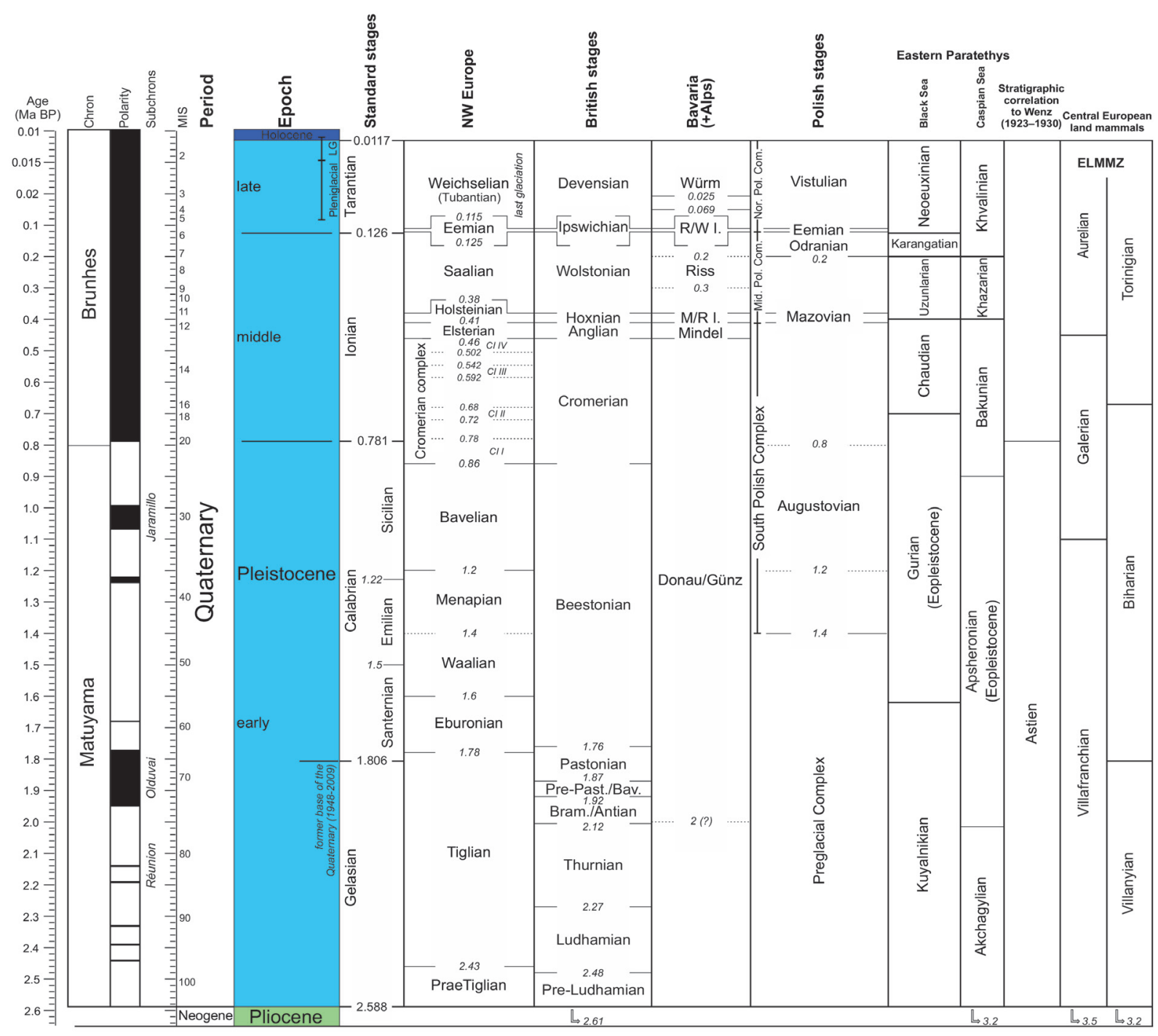

FIGURE 2. Stratigraphic table of the Pleistocene based on the global chronostratigraphic correlation table for the last 2.7 million years (Cohen and Gibbard, 2011). The Marine Isotope Stages (MIS) follow Lisiecki and Raymo (2005). The colour code corresponds to the colours in the supplied kml-file. The dates are expressed in Ma BP. The first $0.1 \mathrm{Ma}$ are not to scale. For information about the sources see 'Methods'. Abbreviations used in the chart: Bram. = Bramertonian, $\mathrm{Cl}=$ Cromerian Interglacial, $\mathrm{LG}=$ Last Glacial, Mid. Pol. Com. $=$ Middle Polish Complex, M/R I. $=$ Mindel $/$ Riss Interglacial, Nor. Pol. Com. = North Polish Complex, Pre-Past./Bav. $=$ Pre-Pastonian $/$ Baventian, R/W I. = Riss/Würm Interglacial.

years (Cohen and Gibbard, 2011). Accordingly, they are products of composition of several publications. In particular, the proposed age boundaries for the chronozones of the Holocene are largely based on Magny (1995), Litt et al. (2001), Bitinas et al. (2002) and Mouthon and Magny (2004, 2014). The Ages of Man are partly supplemented by Holzhauser et al. (2005) and Grosjean et al. (2007). The Baltic stages are after Hyvärinen (1984), Jensen et al. (1999), Damušytè (2009) and Wojciechowski (2011). The Postglacial is defined according to Dehm (1967), the Late Glacial is based on Bos et al. (2001) and Litt et al. (2001) and the Pleniglacial on Bos et al. (2001). For the Pleistocene, the standard Italian stages, the North West European stages and the British stages are derived from Cohen and Gibbard (2011). The Bavarian stages are taken from Doppler et al. (2011). The outline of the Polish stages was taken from Ber (2005) and Lindner et al. (2013). The ambiguous terms Diluvial/Ältere Kalktuffe and Alluvial/Jüngere Kalktuffe/ Subrecent were assigned to Pleistocene (1.806- 


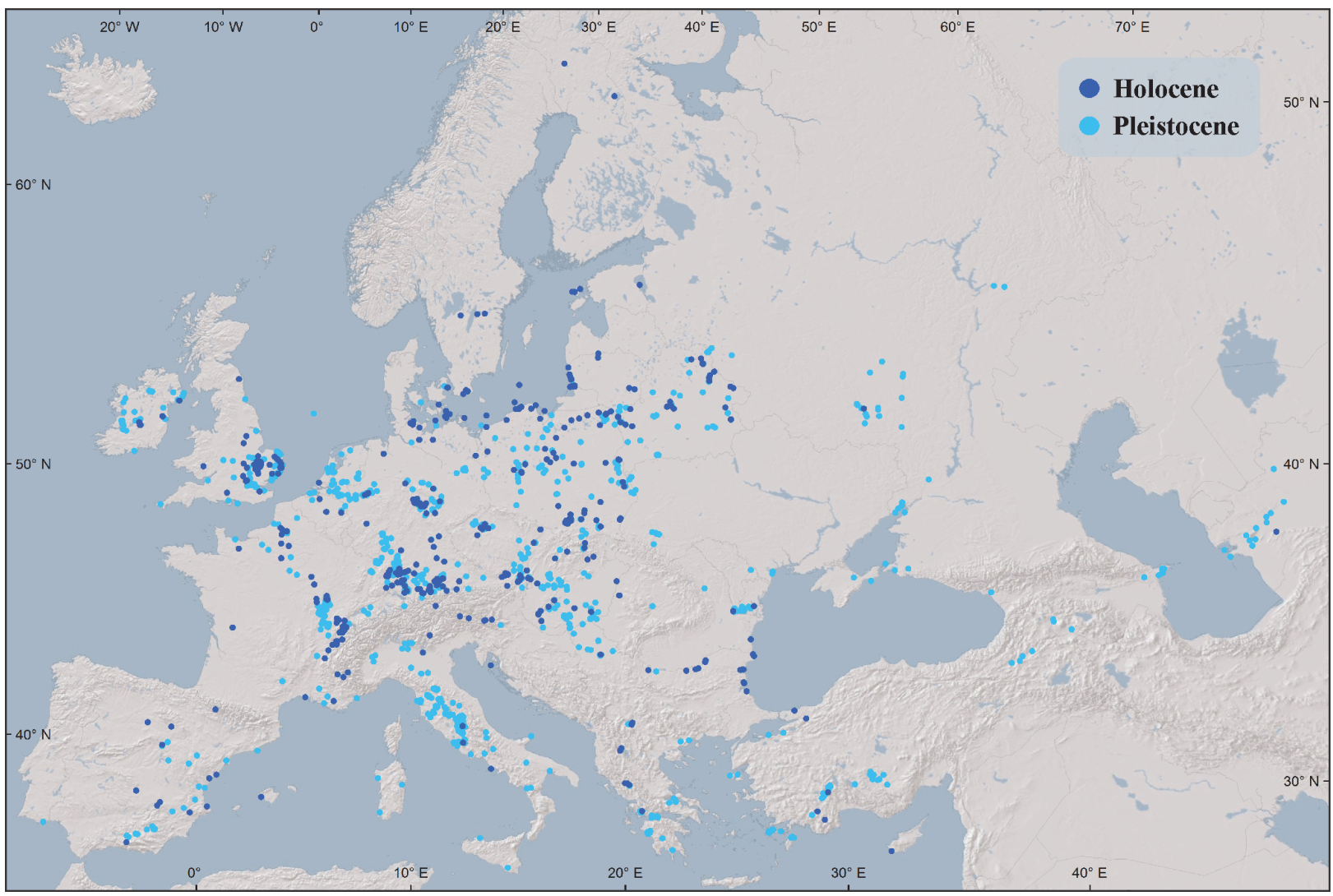

FIGURE 3. European Pleistocene and Holocene localities with fossil and subfossil freshwater gastropods as recorded from the published literature. For complete data see Appendix 1.

$0.0117 \mathrm{Ma})$ and Holocene $(0.0117-0 \mathrm{Ma})$, respectively. The chronostratigraphic tables are as complete as possible, including the main units that were used to describe the age of the respective sites. Nevertheless, some terms (e.g., local names of Glacial-Interglacial stages) are omitted due to space constrains and readability.

\section{DATA DESIGN}

In total, the list comprises 1487 entries on Quaternary localities, derived from publications of the nineteenth century up to the present. The stratigraphic time interval covered is $0-2.588 \mathrm{Ma}$. All localities are fully georeferenced, expect for 14 of which the geographic precision is restricted to country level and thus, they are not drawn on the map. In these cases the name of the site as provided in the publication could not be matched to a known geographic name.

The current dataset's latitude ranges from $c$. $34^{\circ} \mathrm{N}$ to $68^{\circ} \mathrm{N}$ and the longitude runs from c. $10^{\circ}$ $\mathrm{W}$ to $58^{\circ} \mathrm{E}$ (Figure 3 ). The obvious scarcity of points northern than $59^{\circ} \mathrm{N}$ can be explained by the glacial erosion, while the lack of data for Eastern
Europe is mainly due to the unavailability (to us) of regional publications. An overview of the geographic and stratigraphic dataset of the Quaternary localities is provided as an Acrobat PDF file (.pdf) (summarized in Appendix 1). It is accompanied by a Keyhole Markup Language file (.kml) (see Appendix 2), which can be easily visualized in different Geographic Information Systems, such as Google $^{\mathrm{TM}}$ Earth and ESRI® ArcGIS ${ }^{\mathrm{TM}}$. In addition, the placemarks of the $\mathrm{kml}$-file are color-coded to correspond with each epoch (i.e., Holocene - dark blue, Pleistocene - light blue). Below a full explanation of each dataset field is given (following Neubauer et al., 2015):

ID. Database identification number of record.

Locality. Name of the locality with indication of sample (when applicable). Locality is equal to the name of the parent administrative unit when precise data is unavailable.

Administrative unit. Parent geographic category, e.g., the village or city the locality belongs to.

Country. The current country the locality is situated in. 
Alternate spellings. Historical, different or misspelled names attributed to the locality.

Latitude. in decimal degrees, using the geographic coordinate system WGS 1984.

Longitude. in decimal degrees, using the geographic coordinate system WGS 1984.

Geographic precision. Estimate of accuracy of the coordinates $(1=100 \mathrm{~m}$ confidence radius, $2=5 \mathrm{~km}$ confidence radius, $3=20 \mathrm{~km}$ confidence radius, $4=$ only the political district is known, $5=$ only the country is known).

Stratigraphic age. Age of the deposits. Additional information is in brackets, when the absolute ages vary between different publications or palaeogeographic settings (e.g., former base of the Quaternary before 2009). When the age was uncertain or unavailable, the most probable stratigraphic age was assigned by the authors, often based on information from regional geology. The assigned age of a locality only corresponds to layers with the recorded freshwater gastropod assemblage of lacustrine, fluvial or brackish origin. Thus, the total stratigraphic range represented by a section might be larger.

Age, lower boundary. Absolute age of lower boundary of given stratigraphic interval as derived from the literature.

Age, upper boundary. Absolute age of upper boundary of given stratigraphic interval as derived from the literature. Localities with stratigraphic ages crossing the Pleistocene-Holocene or Pliocene-Pleistocene boundary were assigned to the epoch which constitutes the larger portion (e.g., Villafranchian is assigned to Pleistocene). This convention avoids duplicates and potential overlap with the list of Miocene-Pliocene localities by $\mathrm{Neu}-$ bauer et al. (2015).

Epoch. The epoch the locality is assigned to.

Reference. Publication reference for the stratigraphic information.

\section{ACKNOWLEDGMENTS}

We are grateful to the following people for help with literature, stratigraphic classifications and/or other assistance: W.P. Alexandrowicz (AGH University of Science and Technology, Krakow), V.V. Anistratenko (Schmalhausen Institute of Zoology of the Ukrainian National Academy, Kiev), D. Esu (University of Rome), S. Herzog-Gutsch (Natural History Museum Vienna), J. Hupuczi (University of Szeged), G. lliopoulos (University of Patras), A. Kourgli (Natural History Museum Vienna), W. Kuijper (Universiteit Leiden), N. Limondin-Lozouet (French National Center for Scientific Research),
R. Pouwer (Naturalis Biodiversity Center), M.A. Salamon (University of Silesia), A. Sanko (Belarusian State University), M. Szymanek (University of Warsaw), P. Sümegi (University of Szeged), F.P. Wesselingh (Naturalis Biodiversity Center), and K. Zágoršek (Praha). We also thank two anonymous reviewers for their comments and literature suggestions that significantly improved the manuscript. The project was financially supported by the Austrian Science Fund (FWF project no. P25365-B25: "Freshwater systems in the Neogene and Quaternary of Europe: Gastropod biodiversity, provinciality, and faunal gradients") and the European Commission's Research Infrastructure Action via the SYNTHESYS Programme.

\section{REFERENCES}

Alexandrowicz, S.W. and Alexandrowicz, W.P. 2010. Molluscs of the Eemian Interglacial in Poland. Annales Societatis Geologorum Poloniae, 80:69-87.

Alexandrowicz, W.P. 1999. Evolution of the malacological assemblages in north Poland during the Late Glacial and Early Holocene. Folia Quaternaria, 70:3969.

Alexandrowicz, W.P. 2013. Late Glacial and Holocene molluscan assemblages in deposits filling palaeolakes in Northern Poland. Studia Quaternaria, 30:517.

Ber, A. 2005. Polish Pleistocene stratigraphy - A review of interglacial stratotypes. Netherlands Journal of Geosciences, 84:61-76.

Bitinas, A., Damušytè, A., Stančikaitè, M., and Aleksa, P. 2002. Geological development of the Nemunas River Delta and adjacent areas, West Lithuania. Geological Quarterly, 46:375-389.

Böger, H. 1983. Stratigraphische und tektonische Verknüpfungen kontinentaler Sedimente des Neogens im Ägäis-Raum. Geologische Rundschau, 72:771-814.

Bos, J.A.A., Bohncke, S.J.P., Kasse, C., and Vandenberghe, J. 2001. Vegetation and Climate during the Weichselian Early Glacial and Pleniglacial in the Niederlausitz, eastern Germany-macrofossil and pollen evidence. Journal of Quaternary Science, 16:269-289.

Cohen, K.M. and Gibbard, P. 2011. Global chronostratigraphical correlation table for the last 2.7 million years. Subcommission on Quaternary Stratigraphy (International Commission on Stratigraphy), Cambridge, England.

Damušytè, A. 2009. Late Glacial and Holocene subfossil mollusc shells on the Lithuanian Baltic Sea coast. Baltica, 22:111-122.

Dehm, R. 1967. Die Landschnecke Discus ruderatus im Postglazial Süddeutschlands. Mitteilungen der Bayerischen Staatssammlung für Paläontologie und Historische Geologie, 7:135-155. 
Doppler, G., Kroemer, E., Konrad, R., Wallner, J., Jerz, H., and Grottenthaler, W. 2011. Quaternary Stratigraphy of Southern Bavaria. E \& G Quaternary Science Journal, 60:329-365.

Esu, D. and Girotti, O. 1975. La malacofauna continentale del Plio-Pleistocene dell'Italia centrale. I. Paleontologia. Geologica Romana, 13:203-294.

Frank, C. 2006. Plio-pleistozäne und holozäne Mollusken Österreichs. Teil 1. Mitteilungen der Prähistorischen Kommission, 62:1-395.

Geyer, D. 1912. Die Molluskenfauna der diluvialen und postdiluvialen Kalktuffe des Diessener Tales, eine biologisch-geologische Studie. Mitteilungen der Geologischen Abteilung des K. Württembergischen Statistischen Landesamts, 9:1-55.

Gibbard, P.L., Head, M.J., Walker, M.J.C., and the Subcommission on Quaternary Stratigraphy. 2010. Formal ratification of the Quaternary System/Period and the Pleistocene Series/Epoch with a base at 2.58 Ma. Journal of Quaternary Science, 25:96-102.

Gradstein, F.M., Ogg, J.G., Schmitz, M.D., and Ogg, G.M. 2012. The Geologic Time Scale 2012, 2 volumes. Elsevier, Oxford.

Grosjean, M., Suter, P.J, Trachsel, M., and Wanner, H. 2007. Ice-borne prehistoric finds in the Swiss Alps reflect Holocene glacier fluctuations. Journal of Quaternary Science, 22:203-207.

Holzhauser, H., Magny, M., and Zumbühl, H.J. 2005. Glacier and lake-level variations in west-central Europe over the last 3500 years. The Holocene, 15:789-801.

Hóračová, J., Ložek, V., and Juřičková, L. 2015. List of malacologically treated Holocene sites with brief review of palaeomalacological research in the Czech and Slovak Republics. Quaternary International, 357:207-211.

Hyvärinen, H. 1984. The Mastogloia stage in the Baltic Sea history: diatom evidence from southern Finland. Bulletin of the Geological Society of Finland, 56:99115.

Jensen, J.B., Bennike, O., Witkowski, A., Lemke, W., and Kuijpers, A. 1999. Early Holocene history of the southwestern Baltic Sea: the Ancylus Lake stage. Boreas, 28:437-453.

Kennard, A.S. and Woodward, B.B. 1917. The Post-Pliocene non-marine Mollusca of Ireland. Proceedings of the Geologists' Association, 28:109-190.

Kennard, A.S. and Woodward, B.B. 1922. The Post-Pliocene non-marine Mollusca of the East of England. Proceedings of the Geologists' Association, 33:104142.

Leng, M. and Marshall, J.D. 2004. Palaeoclimate interpretation of stable isotope data from lake sediment archive. Quaternary Science Reviews, 23:811-831.

Limondin-Lozouet, N., Preece, R.C., and Antoine, P. 2013. The Holocene tufa at Daours (Somme Valley, northern France): Malacological succession and palaeohydrological implications. Boreas, 42:650663.
Lindner, L., Marks, L., and Nita, M. 2013. Climatostratigraphy of interglacials in Poland: Middle and Upper Pleistocene lower boundaries from a Polish perspective. Quaternary International, 292:113-123.

Lisiecki, L.E. and Raymo, M.E. 2005. A Pliocene-Pleistocene stack of 57 globally distributed benthic $\delta^{180}$ records. Paleoceanography, 20:PA1003.

Litt, T., Brauer, A., Goslar, T., Merkt, J., Bałaga, K., Müller, H., Ralska-Jasiewiczowa, M., Stebich, M., and Negendank, J.F.W. 2001. Correlation and synchronisation of Late glacial continental sequences in northern central Europe based on annually laminated lacustrine sediments. Quaternary Science Reviews, 20:1233-1249.

Ložek, V. 1964. Quartärmollusken der Tschechoslovakei. Rozpravy Ústředního Ústavu Geologického 31, Praha.

Magny, M. 1995. Paleohydrological Changes in Jura (France), and Climatic Oscillations around the North Atlantic from Allerød to Preboreal. Géographie physique et Quaternaire, 49:401-408.

Meijer, T. and Preece, R.C. 1996. Malacological evidence relating to the stratigraphical position of the Cromerian, p. 53-82. In Turner, C. (ed.), The Early Middle Pleistocene in Europe. A.A. Balkema, Rotterdam, Brookfield.

Mouthon, J. and Magny, M. 2004. Malacological history of Lake Annecy (France): a comparison of Late Holocene (since $4700 \mathrm{BC}$ ) and present mollusc assemblages. Archiv für Hydrobiologie, 160: 555-573.

Mouthon, J. and Magny, M. 2014. Unprecedented changes in mollusc assemblages of the littoral zone in the two largest peri-Alpine French lakes since the last 4500 years. Journal of Limnology, 73:20-30.

Neubauer, T.A., Harzhauser, M., Georgopoulou, E., and Wrozyna, C. 2014. Population bottleneck triggering millennial-scale morphospace shifts in endemic thermal-spring melanopsids. Palaeogeography, Palaeoclimatology, Palaeoecology, 414:116-128.

Neubauer, T.A., Georgopoulou, E., Harzhauser, M., Mandic, O., Kroh, A., and Esu, D. 2015. Synopsis of European Neogene localities with freshwater gastropod faunas with data on geography and updated stratigraphy. Palaeontologia Electronica, 18.1.3T:17; palaeo-electronica.org/content/2015/1153-neogene-freshwater-gastropods

Popov, S.V., Rögl, F., Rozanov, A.Y., Steininger, F.F., Shcherba, I.G., and Kovac M. 2004. LithologicalPaleogeographic maps of Paratethys. 10 Maps Late Eocene to Pliocene. Courier Forschungsinstitut Senckenberg, 250:1-46.

Rögl, F. 1998. Palaeogeographic considerations for Mediterranean and Paratethys Seaways (Oligocene to Miocene). Annalen des Naturhistorischen Museums in Wien, Series A, 99:279-310.

Sanko, A.F. 2007. Quaternary freshwater molluscs of Belarus and neighbouring regions of Russia, Lithuania, Poland (field guide). Institute of Geochemistry 
and Geophysics, National Academy of Sciences, Belarus. (In Russian)

Skompski, S. 1989. Role of malacologic investigations for stratigraphy of the Quaternary of southeastern Poland. Kwartalnik Geologiezny, 33:525-540.

Sparks, B.W. 1961. The ecological interpretation of Quaternary non-marine Molluscs. Proceedings of the Linnean Society of London, 172:71-80.

Sümegi, P., Gulyás, S., and Jakab, G. 2008. Holocene paleoclimatic and paleohydrological changes in Lake Balaton as inferred from a complex quantitative environmental historical study of a lacustrine sequence of the Szigliget embayment. Documenta Praehistorica, 35:33-43.

Szymanek, M. 2011. Climate oscillations of the Holsteinian (Mazovian) Interglacial recorded in shell morphometry of Viviparus diluvianus (Kunth, 1865) from eastern Poland. Quaternary International, 241:143159.

Szymanek, M. 2013. Palaeoecology of the Holsteinian lake in vicinity of Wilczyn (eastern Poland) based on molluscan studies. Geological Quarterly, 57:637648.
Szymanek, M. 2014. Environmental changes of the Mazovian (Holsteinian / MIS 11) palaeolake near Szymanowo (eastern Poland) in the light of malacological analysis. Acta Geologica Polonica, 64:249260.

Szymanek, M., Nitychoruk, J., Trammer, J., and Bińka, K. 2005. Influence of climate on the variability of snails of the genus Viviparus in deposits of the Holsteinian (Mazovian) Interglacial from Ortel Królewski, eastern Poland. Boreas, 43:335-344.

Welter-Schultes, F.W. 2012. European non-marine molluscs, a guide for species identification. Planet Poster Editions, Göttingen.

Willmann, R. 1981. Evolution, Systematik und stratigraphische Bedeutung der neogenen Süßwassergastropoden von Rhodos und Kos/Ägäis. Palaeontographica Abt. A, 174:10-235.

Wojciechowski, A. 1999. Late Glacial and Holocene lake-level fluctuations in the Kórnik-Zaniemyśl lakes area, Great Poland Lowland. Quaternary Studies in Poland, 16:81-101.

Wojciechowski, A. 2011. Stages of the evolution of the South Baltic coast as recorded in the molluscan fauna. Journal of Coastal Research, ICS2011 Proceedings, 64:711-715. 


\section{APPENDIX 1.}

Complete list of the Pleistocene and Holocene localities. For explanation of the fields see 'Data design'. Available as PDF at palaeo-electronica.org/content/2015/1328-quaternary-gastropods.

\section{APPENDIX 2.}

Interactive visualisation of the data points. Available as zipped file at palaeo-electronica.org/content/2015/1328-quaternary-gastropods. 